\title{
Review Article \\ Protective Role of Cytotoxic T Lymphocytes in Filovirus Hemorrhagic Fever
}

\author{
Kelly Lyn Warfield ${ }^{1}$ and Gene Garrard Olinger ${ }^{2}$ \\ ${ }^{1}$ Vaccine Development, Integrated Biotherapeutics, Inc., 21 Firstfield Road Suite 100, Gaithersburg, MD 20878, USA \\ ${ }^{2}$ Virology Division, The United States Army Medical Research Institute of Infectious Diseases, 1425 Porter Street, Fort Detrick, \\ Frederick, MD 21702, USA
}

Correspondence should be addressed to Kelly Lyn Warfield, kelly@integratedbiotherapeutics.com

Received 29 June 2011; Accepted 21 October 2011

Academic Editor: Hanchun Yang

Copyright ( $) 2011$ K. L. Warfield and G. G. Olinger. This is an open access article distributed under the Creative Commons Attribution License, which permits unrestricted use, distribution, and reproduction in any medium, provided the original work is properly cited.

\begin{abstract}
Infection with many emerging viruses, such as the hemorrhagic fever disease caused by the filoviruses, Marburg (MARV), and Ebola virus (EBOV), leaves the host with a short timeframe in which to mouse a protective immune response. In lethal cases, uncontrolled viral replication and virus-induced immune dysregulation are too severe to overcome, and mortality is generally associated with a lack of notable immune responses. Vaccination studies in animals have demonstrated an association of IgG and neutralizing antibody responses against the protective glycoprotein antigen with survival from lethal challenge. More recently, studies in animal models of filovirus hemorrhagic fever have established that induction of a strong filovirus-specific cytotoxic T lymphocyte (CTL) response can facilitate complete viral clearance. In this review, we describe assays used to discover CTL responses after vaccination or live filovirus infection in both animal models and human clinical trials. Unfortunately, little data regarding CTL responses have been collected from infected human survivors, primarily due to the low frequency of disease and the inability to perform these studies in the field. Advancements in assays and technologies may allow these studies to occur during future outbreaks.
\end{abstract}

\section{Introduction}

The Filoviridae family contains the two genera, Ebolavirus and Marburgvirus. The Marburgvirus genus contains a single species: Lake Victoria Marburg virus (LVMARV). The Ebolavirus genus consists of the four species of Ebola virus (EBOV): Zaire EBOV (ZEBOV), Sudan EBOV (SEBOV), Reston EBOV (REBOV), and Ivory Coast EBOV (ICEBOV). After a recent outbreak in Uganda, a fifth species of EBOV has been proposed [1].

Filoviruses are enveloped, nonsegmented, negativestranded RNA viruses. The virion comprises a core ribonucleocapsid complex surrounded by a lipid envelope which is derived from the host cell plasma membrane. The $\sim 19 \mathrm{~kb}$ noninfectious genome encodes seven structural proteins with the following gene order: $3^{\prime}$ leader, a nucleocapsid protein (NP), structural virion protein (VP) 35 (VP35), a matrix protein VP40, glycoprotein (GP), two additional structural proteins VP30, VP24, and the RNA-dependent
RNA polymerase L protein, and $5^{\prime}$ trailer [2]. VP24 and VP35 have been shown to act as interferon antagonists [3]. Studies employing reconstituted replication systems showed that transcription/replication of MARV requires three of the four proteins (NP, VP35, L), while transcription/replication of EBOV requires all four proteins [4]. For EBOV and MARV, the virus encodes a type I transmembrane glycoprotein (GP) that is responsible for virus binding and entry into host cells, is the only protein known to be located on the surface of the virions and infected cells, and is the likely target of protective antibodies.

The filoviruses cause severe acute hemorrhagic fever in humans, with a high mortality rates. Disease onset is sudden, beginning with fever, malaise, chills, loss of appetite, muscle aches, and headache. These may be followed by abdominal pain, nausea, vomiting, cough, sore throat, arthralgia, diarrhea, and hemorrhage, with death occurring from shock. A maculopapular rash often develops 5 to 7 days into the illness. The mortality observed in outbreaks has ranged from 
$25 \%$ to $90 \%[5,6]$ with ZEBOV causing extensive pathology and having the highest mortality rates. The virus is found throughout the body, but the highest concentrations are in the liver, kidney, spleen, and lungs. Filoviruses primarily replicate in mononuclear phagocytes $[7,8]$ and induce production of proinflammatory cytokines by infected cells [9], which may explain the damage to the lymphatic organs.

Outbreaks of filovirus infection cannot be predicted despite growing evidence that bats are among, and perhaps principle among, the natural reservoirs and/or vector(s) $[10,11]$. Including the human suffering these disease inflict where the diseases are endemic, the viruses also have the potential for accidental importation from epidemic regions. Additionally, filoviruses are stable and can be infectious as aerosols, by the oral and conjunctival routes $[8,12-16]$ making them a bioweapon concern. Supportive care remains the only option for treating patients infected during natural or intentional disease outbreaks. Therefore, it is important to develop vaccines and therapeutics that can be in preventative, postexposure, or therapeutic settings.

\section{Filovirus Vaccines and Therapies}

There are several promising vaccine candidates that have demonstrated immunogenicity and efficacy in animal models of disease. These platforms include the Venezuelan equine encephalitis (VEE) virus-like replicon (VRP), adenovirus 5 (Ad5), vesicular stomatitis virus-(VSV-) based vaccines, and virus-like particles (VLPs) [17, 18]. In early studies, classical approaches were attempted for filovirus vaccines attenuated or inactivated viral preparations; however, protection in primate animal models showed variable and moderate success coupled with the risk of revertants or incomplete inactivation result in these approaches being unacceptable for future use in humans [19-27]. Genetic, virus-vectored, and subunit vaccines have been evaluated in recent years. Early publications reported partial to complete protection against virus challenge in rodents after genegun administration of DNA plasmids containing GP genes, but provided incomplete protection to NHP [19, 28, 29], but more recently, Geisbert et al. demonstrated complete protection against MARV using a DNA vaccine approach [30]. Purified glycoprotein-based vaccine candidates showed moderate success to date in guinea pigs although the quality, potency, and purity of these protein preparations are unclear $[28,31,32]$. Vector-based approaches including replicationincompetent VEE virus replicons, replication-incompetent adenoviral (Ad5) vectored vaccines, as well as live recombinant virus-based approaches using vesicular stomatitis virus (VSV) or parainfluenza have shown significant promise in both rodents and NHP models [23, 26, 33-43]. The vaccine candidates, to date, have identified immunogens, usually the glycoprotein, established minimal effective doses, and most importantly demonstrated efficacy in the highly sensitive macaque models of filovirus disease. In almost all cases of successful vaccination, an association with filovirus-specific IgG with protection has been identified [44].

Currently, there are no medical interventions approved for the treatment of filovirus infections in humans and current standard of care is supportive medical treatment (e.g., fluid replacement, transfusions, antibiotics for prevention of secondary infections) [45]. Multiple approaches have been tested and demonstrated partial to complete protection against lethality in nonhuman primate models including treatment of the coagulopathic diathesis by use of nematode anticoagulant protein c2 (a potent inhibitor of tissue factor-initiated blood coagulation) [46] or recombinant human-activated protein $\mathrm{C}$ (which has a broad spectrum of coagulation-modulating activity) [47], immune modulators such as human-activated protein C [47] therapeutic vaccines [48-50], and gene-specific antivirals [51-54]. The VSV system has been shown to provide highly robust protection when administered to nonhuman primates in a postexposure setting and likely induces both nonspecific innate stimulation as well as virus-specific immunity [48-50]. Antivirals such as siRNA and phosphodiamidate morpholino oligomers that directly inhibit EBOV or MARV replication also appear to be lead candidates for treatment of highly lethal filovirus infections based on highly successful efficacy studies in NHP [51-54]. In all cases, lower peak viral loads are associated with more promising outcomes in humans and NHP $[51,55]$.

In this review, we have summarized the findings of recent investigations on cellular responses against EBOV and their importance in survival from lethal filovirus challenge. Understanding the protective immune responses and immunopathology induced by these viruses may be critical to the advancement of the filovirus vaccine platforms and potentially to postexposure treatment strategies for filovirusinfected individuals.

\section{Global Immune Responses and Immune Interactions after Filovirus Infection}

\subsection{Impaired Innate Immune Responses during Filovirus} Infection. The innate immune system is the cornerstone for recognizing and effectively eliminating viral infections; rapid detection of the microbe and subsequent activation of the host innate immune response is key for developing effective adaptive immunity to invading pathogens. Antigen-presenting cells including monocytes, macrophages, and dendritic cells (DCs) are central in both activation of innate immunity and initiation of adaptive immunity. Antigen-presenting cells drive immune responses by inducing cytokines and chemokines; antigen presentation; interactions with $\mathrm{B}, \mathrm{T}$, and NK cells; and direct cytotoxic activity against target cells [56, 57]. Several key observations support a critical role for innate immunity in filovirus infections.

First, survivors of filovirus infection have an early and short-lived rise in serum chemokines, indicative of innate immune system induction [58-63]. In a recent and relatively large study of EBOV-infected individuals, nonsurvivors develop extremely high levels (5-1000X) of proinflammatory cytokines (IL-1 $\beta$, IL-1RA, IL-6, IL-8, IL-15, and IL-16) and chemokines (MIP- $1 \alpha$, MIP- $1 \beta$, MCP-1, MIF, IP-10 GRO- $\alpha$, and eotaxin) that began rising shortly after disease onset and continuing until the last sampling within 2-3 days before death [63]. Infected monocytes and macrophages may be 
the primary mediators of this inflammatory response and the resulting cytokine and chemokine secretion increases the permeability of endothelial layer and causes induction of shock $[9,64]$. Interestingly, both survivors and non-survivors do not differ in their serum levels of important regulators of adaptive immunity such as IFN- $\alpha$, IFN- $\gamma$, IL-12, IL-17, or TNF [63]. Consistently with these findings, the filoviruses encode interferon antagonists VP24 and VP35, which block interferon production and inhibit downstream interferon signaling [65].

Second, filoviruses evade the immune system by preventing the maturation of DC, the cornerstone of innate and adaptive immunity $[66,67]$, as well as encoding for multiple viral proteins that add in evasion of interferon responses (reviewed in [65]). These data suggest that EBOV may block DC maturation after infection, thereby inhibiting activation of lymphocytes and eliminating those subsets that are most likely to be capable of mounting an effective response to the virus. Both EBOV and MARV readily infect and rapidly replicate in antigen-presenting cells such as monocytes, macrophages, and DCs resulting in the production of large amounts of progeny virus $[9,64,66-70]$. In EBOVinfected macaques, the number of circulating HLA-DR+ cells increases 10X in the blood after infection suggesting that infected DCs may disseminate virus throughout the body after trafficking from the infection site [71]. Despite increased numbers in the circulation, DCs infected by filoviruses fail to mature or become activated and, therefore, fail to induce appropriate NK-, B-, and T cell responses after infection [66, 67]. Activity of monocytes and macrophages may also be dysregulated, although responses of monocytes and macrophages to filovirus infection are a divisive issue in filovirology $[9,64,66,70]$. Certainly, the downstream effects of antigen-presenting cell dysfunction are profound with a marked lack of adaptive immunity noted in fatal cases of filovirus infection.

Third, activation and maintenance of natural killer (NK) cells appears to be vital to protection against lethal filovirus infection [50, 72, 73]; however, NK cells and other lymphocytes are depleted during filovirus infection of human and NHPs $[55,59,60,71]$. The disappearance of $\mathrm{NK}$ and $\mathrm{T}$ cells in the periphery is presumptively due to apoptosis by a yet unidentified mechanism, although a Fas/FasL interaction is likely involved $[14,55,63,74]$. A potential correlation of NK cells with rapid protection against filovirus hemorrhagic fever, induced by rVSV vaccine in a postexposure treatment study in nonhuman primates, was observed [73]. VLPs can also induce rapid and potent innate immune responses in rodents injected with VLPs 1-3 days before challenge with EBOV [72]. Injection with VLPs recruited almost twice the number of NK cells in both the mediastinal lymph node and spleen compared to animals receiving PBS alone [72], suggesting that VLP administration induces NK cell proliferation and/or trafficking in lymphoid tissues VLP-pretreatment of mice lacking functional NK cells [75] or mice depleted of NK cells using antiasialoGM1 antibodies did not protect from EBOV infection, unlike VLPinjected wild-type C57Bl/6 mice [72]. Furthermore, adoptive transfer of NK cells stimulated with VLPs protected naïve mice against EBOV infection and the mechanism of this protective innate immunity requires perforin, but not IFN$\gamma$, [72]. Recently, Wauquier et al. suggested a role of the killer immunoglobulin receptor (KIR) repertoire in fatal outcomes of patients infected with EBOV. KIRs are expressed on the surface of NK and T cells and involved in activation of NK cells $[63,76]$. Together, these data point to a critical role for NK cells in survival from filovirus infection and suggest the cytolytic "killer" functions of NK cells are an important mechanism in promoting survival from EBOV infection.

Subversion of innate immunity combined with a lag in activation of adaptive immune responses likely results in uncontrolled, disseminated, filovirus infection [66-68].

\subsection{Role of $B$ and $T$ Cells in Filovirus Infection. Infected} individuals who succumb to filovirus infection fail to mount a substantial cellular or humoral immune response. In nonsurvivors, activation of immune cells and secretion of cytokines and chemokines are detected early in infection; however, these early cellular responses appear to be attenuated and are not detectable at the time of death while the levels of proinflammatory cytokines and chemokines reach enormous levels before a fatal outcome. Fatal cases of filovirus hemorrhagic fever are associated by a marked lack of detectable adaptive immunity. After onset of symptoms, a massive loss of $\mathrm{CD}^{+}$and $\mathrm{CD} 8^{+} \mathrm{T}$ cells occurs. In fatal cases of disease, gross numbers of $\mathrm{CD}^{+}$and $\mathrm{CD} 8^{+} \mathrm{T}$ cells are greatly reduced in non-survivors as compared to survivor $(6-10 \%$ versus 20-40\%, resp. [63]). Similarly, in a cynomolgus macaque model of EBOV hemorrhagic fever, $\mathrm{CD} 4^{+}$and $\mathrm{CD}^{+}$lymphocyte counts rapidly declined $60-70 \%$ within the first 4 days after infection [71] and phenotypic analysis of the $\mathrm{T}$ lymphocyte subsets demonstrated the lack of a robust immune response to the infection. In the nonhuman primate model, apoptosis of $\mathrm{CD} 8^{+} \mathrm{T}$ cells was observed within 2 days of infection. Similar findings in nonsurvivor human cases and nonhuman primates that succumb to filovirus infection show an increase in the expression of CD95 (Fas) suggests a mechanism for apoptosis involving the Fas/Fas-L cascade $[63,71,77]$ and both upregulation of Fas/FasL and TRAIL are observed in filovirus-infected PBMS or monocytic cells [78]. Interestingly, the number of $\mathrm{CD} 20^{+} \mathrm{B}$ lymphocytes in the blood does not appear to be significantly altered after filovirus infection using the nonhuman primate infection model despite the apparent lack of virus-specific IgG in nonhuman primates and nonsurviving human patients [55, 71].

In EBOV survivors, the early and apparently regulated inflammatory response is quickly followed by a detectable $\mathrm{T}$ cell response with an increase in markers suggesting the activation of cytotoxic T cells (CTL) $[55,58,63]$. Concomitant with detectable $\mathrm{T}$ cell responses, an early and transient IgM is followed quickly by increasing levels of EBOV-specific IgG in EBOV survivors [55, 58, 79]. Survivors develop rapid immune responses that likely clear circulating EBOV early, indicating that a swift induction of the appropriate immune responses in humans can result in survival from filovirus infection [55]. 
Mechanistic studies regarding the role of $\mathrm{B}$ and $\mathrm{T}$ cells are difficult in nonhuman primate models; therefore, a number of studies examining the role of $\mathrm{B}$ and $\mathrm{T}$ cells in protection from lethal filovirus disease have been conducted using a mouse model of EBOV (requiring a mouse-adapted strain for lethal disease [80]). Both $\mathrm{CD}^{+}$and $\mathrm{CD}^{+} \mathrm{T}$ cells are depleted in the blood and spleens after EBOV infection of mice, apparently due to apoptosis, similarly to humans and nonhuman primates; however, subsequent studies have shown that $\mathrm{T}$ cell function is maintained in the remaining cells despite their massive loss in numbers [81, 82]. The number of functional $\mathrm{CD}^{+} \mathrm{T}$ cells that are generated at the late phase of infection is likely too low to control high viral titers although they are sufficient upon transfer to newly infected animals to control the disease and the damage done by the infection could be too severe to overcome at the time the adaptive immune system can mount a response [82]. The mechanisms of lymphocyte apoptosis have been studied using the mouse model of EBOV and it appears that both the intrinsic and extrinsic apoptotic pathways play a role, as evidenced by infection of various knockout mouse models [83]. Unlike the NHP model of EBOV, mice infected with mouse-adapted EBOV have steep declines in circulating B cells although the number of splenic B cells remains constant after infection [81]. Gupta et al. demonstrated a crucial role for $\mathrm{CD}^{+} \mathrm{T}$ cells in the initial clearance of the virus after primary and secondary infections [84]. In this study, they also showed that neither $\mathrm{CD} 4^{+} \mathrm{T}$ cells nor antibodies were required for immediate protection but in the absence of both $\mathrm{B}$ cells and $\mathrm{CD}^{+} \mathrm{T}$ cells, virus antigen was detected late after infection and morbidity was also observed long after the normal time to death [84]. These mouse data indicate that while immediate control of filovirus infection may be achieved by $\mathrm{CD}^{+} \mathrm{T}$ cells alone, $\mathrm{B}$ and $\mathrm{CD}^{+}{ }^{+} \mathrm{T}$ cells are important for long-term control (and possibly clearance) of virus replication.

\section{Immune Mechanisms of Protection from Filovirus Infection}

4.1. Humoral Responses and Role of Antibodies in Protection Filovirus Infection. Humoral responses have long been deemed important for protective immunity against viral infections and, indeed, all those vaccines shown to provide $100 \%$ protection from lethal challenge in NHP have demonstrated the ability to drive filovirus-specific IgG [44]. In the case of the recombinant Ad5 vaccines, survival can be reliably predicted when a vaccinated NHP achieves a certain IgG titer, suggesting that this may be a potential marker for prediction of protection [85]. In the case of VLP vaccines, vaccinated B cell-deficient mice do not mount antibody responses and are not protected from lethal filovirus challenge [86] and a similar relationship between IgG titers against GP and protection from challenge in VLPvaccinated NHPs is observed for both ZEBOV and MARV (unpublished observation).

A great deal of effort has focused on the passive transfer of antibodies to achieve protection and demonstrate a definitive requirement for antibodies in mediating protection from filovirus infection. Passive transfer of serum containing antibodies or purified IgG specific to EBOV or MARV can provide protection in rodent models of disease [87-90]; it is reported sporadically in NHP models [27, 85, 9193]. It may be hypothesized that the inability to date to repeatedly demonstrate protection in NHP using antibodybased therapeutics is due to limitations on dosages and frequency of treatment, although a cellular component may be critical for protection whether it is part of the antibody therapy or induced naturally after infection. The serum and antibody studies have focused on vaccine-induced polyclonal antibodies or monoclonal antibodies to EBOV or MARV GP [87-90]. Antibodies specific for other viral proteins have been unsuccessful in challenge studies in rodents $[94,95]$.

After successful protection after immunotherapy, de novo immune responses were observed in passively transferred animals. Most notably the induction of virus-specific functional $\mathrm{T}$ cell responses to other viral proteins not present in the original passive transfer inoculum has been reported emphasizing the role of $\mathrm{T}$ cell responses to protection even during passive transfer [96]. In these models, the antibody likely provides control of viral replication while de novo functional and specific $\mathrm{T}$ cell responses are generated to limit and clear virus infection. Studies are underway to more specifically and thoroughly assess antibody treatment regimens in NHP models and the evaluation of subsequent immune responses by the treated host.

4.2. Role of T Cells in Protective Efficacy against Filovirus Hemorrhagic Fever. A critical role in vaccine-induced protection was identified for T cells by VLP vaccination of $\alpha / \beta$-T cell deficient mice and further refined to an absolute requirement for $\mathrm{CD}^{+} \mathrm{T}$ cells using $\beta 2 \mathrm{~m}$-deficient mice [86]. Additionally, multiple $\mathrm{CD}^{+}$CTL epitope-specific responses for EBOV and MARV have been identified in mice $[86,96,102]$, which are summarized in Tables 1 and 2. In a thorough study of murine CD8 T cell responses, mice were vaccinated with VRP containing each of the EBOV antigens (GP, NP, VP24, VP30, VP35, and VP40; all viral proteins except the polymerase [96]) and $\mathrm{CD}^{+} \mathrm{T}$ cells specific for the viral proteins were identified using splenocytes from vaccinated mice by flow cytometry intracellular cytokine assays. Adoptive transfer of the $\mathrm{CD}^{+}$cytotoxic $\mathrm{T}$ cells was performed using cells expanded by peptide restimulation and these studies demonstrated the ability to protect naive mice from EBOV challenge. Transfer of MARV GP- and NP-specific CD8 ${ }^{+}$ $\mathrm{T}$ cells can also provide protection against lethal infection in naïve mice [102]. It is important to note that in these studies other $\mathrm{CD}^{+} \mathrm{T}$ cell epitope virus-specific responses were detected but were not demonstrated to be protective; however, these nonfunctional $\mathrm{CD}^{+}$responses were less likely to demonstrate ex vivo lytic activity [96]. Together these studies demonstrate that adoptive transfer of functional virus-specific $\mathrm{CD}^{+} \mathrm{T}$ cell responses can provide protection in rodent models of disease. Importantly, preliminary data have also suggested a role for $\mathrm{T}$ cells in viral clearance in NHP by immunodepletion of vaccinated animals [91]. By targeting the $\mathrm{T}$ cell surface antigen $\mathrm{CD} 3$ with a mAb toxin conjugate, FN18-CRM9, that depleted circulating $\mathrm{CD}^{+} \mathrm{T}$ 
TABLE 1: ZEBOV protein sequences recognized by murine CD8 ${ }^{+} \mathrm{T}$ cells. The table is adapted and expanded from [97].

\begin{tabular}{|c|c|c|c|c|c|}
\hline ZEBOV protein & Epitope sequence & Amino acid position & Restriction & Protective $^{\mathrm{a}}$ & Reference \\
\hline \multirow{5}{*}{ Glycoprotein } & VSTGTGPGAGDFAFHK & $141-155$ & $\mathrm{H}-2^{\mathrm{d}}$ & Yes & {$[96,98]$} \\
\hline & LYDRLASTVI & $161-169$ & $\mathrm{H}-2^{\mathrm{d}}$ & NT & {$[25,86,98]$} \\
\hline & EYLFEVDNL & $231-239$ & $\mathrm{H}-2^{\mathrm{d}}$ & NT & {$[25,98]$} \\
\hline & WIPYFGPAAEGIYTE & $531-545$ & $\mathrm{H}-2^{\mathrm{b}}$ & No & {$[86,96]$} \\
\hline & TELRTFSI & $577-584$ & $\mathrm{H}-2^{\mathrm{k}}$ & NT & [99] \\
\hline \multirow{8}{*}{ Nucleoprotein } & VYQVNNLEEIC & $44-52$ & $\mathrm{H}-2^{\mathrm{b}}$ & Yes & {$[37,96,100]$} \\
\hline & GQFLFASL & $148-156$ & $\mathrm{H}-2^{\mathrm{b}}$ & Yes & {$[96]$} \\
\hline & FLSFASLFL & $150-159$ & HLA-A2.1 & NT & {$[101]$} \\
\hline & RLMRTNFLI & $202-210$ & HLA-A2.1 & NT & [101] \\
\hline & SFKAALSSLA & $279-287$ & $\mathrm{H}-2^{\mathrm{d}}$ & Yes & {$[96,100]$} \\
\hline & FQQTNAMVT & $388-396$ & $\mathrm{H}-2^{\mathrm{b}}$ & NT & {$[100]$} \\
\hline & KLTEAITAA & $404-412$ & HLA-A2.1 & NT & {$[101]$} \\
\hline & DAVLYYHMM & $663-671$ & $\mathrm{H}-2^{\mathrm{b}}$ & Yes & {$[96]$} \\
\hline \multirow{3}{*}{ VP24 } & KFINKLDALH & $159-168$ & $\mathrm{H}-2^{\mathrm{d}}$ & Yes & \multirow{3}{*}[96]{} \\
\hline & NYNGLLSSI & $171-179$ & $\mathrm{H}-2^{\mathrm{d}}$ & Yes & \\
\hline & PGPAKFSLL & $214-222$ & $\mathrm{H}-2^{\mathrm{d}}$ & Yes & \\
\hline \multirow{4}{*}{ VP30 } & \multirow{2}{*}{ KFSKSQLSLLCETHLR } & \multirow{2}{*}{$181-196$} & $\mathrm{H}-2^{\mathrm{d}}$ & Yes & \multirow{4}{*}[96]{} \\
\hline & & & $\mathrm{H}-2^{\mathrm{b}}$ & Yes & \\
\hline & \multirow{2}{*}{ DLQSLIMFITAFLNI } & \multirow{2}{*}{$231-245$} & $\mathrm{H}-2^{\mathrm{d}}$ & Yes & \\
\hline & & & $\mathrm{H}-2^{\mathrm{b}}$ & Yes & \\
\hline \multirow{5}{*}{ VP35 } & CDIENNPGL & $45-53$ & $\mathrm{H}-2^{\mathrm{b}}$ & Yes & \multirow{5}{*}[96]{} \\
\hline & MVAKYDHL & $138-145$ & $\mathrm{H}-2^{\mathrm{b}}$ & Yes & \\
\hline & TVPQSVREAFNNL & $190-202$ & $\mathrm{H}-2^{\mathrm{d}}$ & Yes & \\
\hline & RNIMYDHL & $225-323$ & $\mathrm{H}-2^{\mathrm{b}}$ & Yes & \\
\hline & PGFGTAFHQLVQVICK & $233-248$ & $\mathrm{H}-2^{\mathrm{d}}$ & Yes & \\
\hline \multirow{4}{*}{ VP40 } & LRIGNQAFLQEFVLPP & $150-165$ & $\mathrm{H}-2^{\mathrm{b}}$ & Yes & {$[86,96]$} \\
\hline & AFLQEFVLPPVQLPQ & $160-175$ & $\mathrm{H}-2^{\mathrm{d}}$ & Yes & {$[96]$} \\
\hline & YFTFDLTALK & $171-180$ & $\mathrm{H}-2^{\mathrm{d}}$ & Yes & {$[86,96]$} \\
\hline & TESPEKIQAI & $232-241$ & $\mathrm{H}-2^{\mathrm{d}}$ & Yes & {$[86,96]$} \\
\hline
\end{tabular}

${ }^{a}$ Protection from lethal challenge demonstrated by either peptide vaccination or by adoptive transfer experiments (Yes, $>50 \%$ protection observed). NT: Not tested.

lymphocytes by $>85 \%$ relative to starting levels, macaques vaccinated and treated with irrelevant IgG but not those animals vaccinated with ZEBOV GP-expressing adenovirus and depleted of $\mathrm{CD}^{+}$T cells using FN18-CRM9 survived, suggesting a key role for $\mathrm{T}$ cells in protection using the adenovirus-based vaccine [91]. Since $\mathrm{CD}^{+} \mathrm{T}$ cell responses against ZEBOV are observed in macaques vaccinated with the adenovirus-based vaccine, the authors then used a CD8 $\alpha$ chain-specific antibody, cM-T807, which efficiently clears $\mathrm{CD}^{+}$cells from blood, spleen, lymph nodes, and liver. In this study, four of five cM-T807 treated and previously vaccinated macaques succumbed to $Z E B O V$ while all naïve controls animals died and those vaccinated and not immunodepleted all survived. A statistically significant decrease in protection was observed in the cM-T807 immuno-depleted vaccinated animals compared to the not immunodepleted and vaccinated; however, an extension in the time to death (TTD) was observed when comparing the immunodepleted, vaccinated macaques (TTD days 10-14) as compared to the two naive animals (TTD day 8 for both). Together, these data suggest that $\mathrm{CD}^{+} \mathrm{T}$ cells are a key component of protection mediated by the GP-expressing recombinant adenovirus vaccine in the context of a ZEBOV challenge but there may be other immune mechanisms involved [91].

Studies have also demonstrated a less important role for $\mathrm{CD}^{+} \mathrm{T}$ cells in protection by filovirus vaccines [86] and, unfortunately, the role of $\mathrm{CD}^{+} \mathrm{T}$ cells was not assessed in the aforementioned mechanistic studies in nonhuman primates by Sullivan et al. [91] Existing efforts are focused on the identification of $\mathrm{CD}^{+}{ }^{+} \mathrm{T}$ cell responses and their role in EBOV and MARV infection, especially given their dominance in responses in vaccinated humans $[103,104]$.

\section{Critical Role for CTL Responses in Protective Efficacy against Lethal Filovirus Disease}

5.1. Identification of Novel CD8 CTL Epitopes Recognized by EBOV- and MARV-Specific CTLs. The discovery and 
TABLE 2: MARV protein sequences recognized by murine $\mathrm{H}-2^{\mathrm{d}} \mathrm{CD} 8^{+} \mathrm{T}$ cells. Summary of data is from [102].

\begin{tabular}{|c|c|c|c|c|}
\hline MARV protein & 15-mer peptide sequence & Minimal peptide & Amino acid position & $\begin{array}{c}\text { Adoptive transfer } \\
\text { protection }^{\mathrm{b}}\end{array}$ \\
\hline \multirow{8}{*}{ Glycoprotein } & FLISLILIQGTKNLP & ILIQGTKNL & $11-19$ & 50 \\
\hline & ILIQGTKNLPILEIA & QGTKNLPIL & $14-22$ & 20 \\
\hline & TCYNISVTDPSGKSL & VTDPSGKSL & $97-105$ & NT \\
\hline & SGKSLLLDPPTNIRD & LLLDPPTNI & $105-113$ & 0 \\
\hline & SPPPTPSSTAQHLVY & TPSSTAQHL & $420-428$ & 0 \\
\hline & GILLLLSIAVLIALS & LLLSIAVLI & $659-667$ & 100 \\
\hline & LSIAVLIALSCICRI & LSIAVLIAL & $661-669$ & 20 \\
\hline & LIALSCICRIFTKYI & IALSCICRI & $667-675$ & 40 \\
\hline \multirow{3}{*}{ Nucleoprotein } & AINSGIDLGDLLEGG & NSGIDLGDL & $43-51$ & 80 \\
\hline & KFNTSPVAKYLRDAG & NTSPVAKYL & $73-81$ & 20 \\
\hline & EPHYSPLILALKTLE & HYSPLILAL & $108-116$ & 10 \\
\hline VP40 & QHKNPNNGPLLAISG & KNPNNGPLL & $218-226$ & 40 \\
\hline
\end{tabular}

a mer peptide sequence derived from HLA binding predictions.

${ }^{b}$ Percentage of animals protected from lethal challenge with mouse-adapted Marburg virus after adoptive transfer of CD8 lymphocytes specific for the 9-mer peptide sequences.

NT: not tested.

identification of virus-specific CTL epitopes have primarily been based on computer algorithms or the use of overlapping synthetic peptides of the viral proteins. The protective capacity of the CTL virus-specific epitopes has been demonstrated in passive transfer studies, vaccination, and in the analysis of postchallenge immune responses in mice $[82,86,96,102]$. Interestingly, solid protective efficacy of adoptively transferred $\mathrm{CD} 8^{+}$epitopes has been strongly associated with lytic function, primarily based on chromium release assays. Improved algorithms, lower-cost overlapping peptides, and the use of HLA binding tetramers and other class I methodologies will assist the assessment of human and NHP responses. Future efforts will be focused on the use of these tools and emerging tools to identify $\mathrm{CD} 8^{+}$and $\mathrm{CD} 4^{+}$ epitopes in mice and $\mathrm{CD} 8^{+}$and $\mathrm{CD} 4^{+} \mathrm{T}$ cell responses NHP and humans.

To date, the use of tetramer and similar technologies offers the ability to analyze the $\mathrm{CD} 8^{+} \mathrm{T}$ cell virus epitopespecific frequency, phenotypes, and functional abilities without ex vivo expansion. However, with macaque models of disease, this powerful approach is limited for a variety of reasons. First, most vaccine work has focused on the use of the cynomolgus macaque (Macaca fascicularis) animal model, for which limited defined Mamu major histocompatibility complex class I molecules are available for use in cellular assays. Second, the rhesus macaque model (Macaca mulatta) has two subspecies, the Indian Rhesus and the Chinese Rhesus, that have been shown to have different genetic backgrounds and have different disease outcomes for some virus infections such as HIV [105-108]. Most importantly, the common reagents for Mamu class I haplotypes used in other diseases (i.e., HIV) are rarely seen in the Chinese rhesus subspecies used in filovirus research. Switching to Indian rhesus macaques could possibly alter the disease course, as is seen with cynomolgus versus rhesus macaques, and would complicate future studies because the subspecies availability is more limited than Chinese rhesus. Therefore, better defining the Mamu class I haplotypes and development of common Mamu class I cellular assays will be critical for future studies to identify important $\mathrm{T}$ cell responses in protected macaques.

5.2. Potential for CTLs as a Cocorrelate of Protection in NHP Studies. Nonlethal infection or vaccination generates complex responses in the host, which include innate and adaptive arms of the immune system. For filovirus vaccines, successful vaccination has generated a protective immune response protecting animals from lethal virus challenges. While both antibody responses and cellular responses have been monitored in past studies, the analysis of these responses was secondary to the objective of assessing the vaccine candidate's efficacy in the animal model. While we are unsure of the contribution of $\mathrm{B}$ and $\mathrm{T}$ cell responses during vaccination, the collective data suggest that both are necessary for viral clearance $[44,85,86]$. Currently, the focus has shifted to advancing the discovery of correlate(s) and surrogate(s) assays of immunity after vaccination. These steps are critical to advance the vaccines through the FDA "animal rule" licensure and eventual human-use of the vaccine(s) [109].

After successful vaccination, adaptive responses to the glycoprotein encompass both humoral and cellular immune responses [44]. Existing assays in the laboratory have relied on assessing the antibody titers and cellular responses $\left(\mathrm{CD}^{+}\right.$and $\mathrm{CD}^{+} \mathrm{T}$ cell responses) after vaccination or virus exposure. For assessing antibody responses, virus GPspecific IgG antibody titers have been assessed by quantitative antigen ELISA and by assessing the functionality of these responses in virus-neutralizing assays [85]. In mice and, retrospectively, in most NHP studies, antibody titers against EBOV GP and $\mathrm{T}$ cell responses correlated well with successful vaccination [96]. However, these assays are 
not always predictive as high titer nonprotective antibody responses have been observed (unpublished observations) and nonneutralizing but protective antibody responses have been described [87]. Therefore, as described by Sullivan et al., $\mathrm{T}$ cell responses are proposed as a cocorrelate with the antibody data from vaccinated animals [85].

\subsection{Current Status of CTL Assays for Filovirus Vaccine Stud-} ies: Measuring "Good" Cellular Immune Responses. Without assessing ELISA antibody titers, examining $\mathrm{T}$ cell responses after vaccination has been less predictive when used in outbred populations, specifically macaques. This is likely due to the complexity of measuring cellular immunity following vaccination. Measuring cellular immune responses is difficult since the assays are laborious, tedious, difficult to replicate, and expensive. Likewise, immunogen quality (peptides or protein) used in the assays is paramount and currently poorly understood for filoviruses. Unlike most humoral assays, cellular assays are typically performed ex vivo, may require in vitro stimulation, preparation of autologous target cells and require difficult-to-obtain reagents and equipment. In addition, the performance criteria for these assays are optimal with freshly isolated, not cryopreserved, peripheral blood mononuclear cells (PBMCs). To maximize the ability to measure cellular responses, a number of assays have been utilized to assess effector functions of $\mathrm{CD}^{+}$and $\mathrm{CD}^{+}{ }^{+} \mathrm{T}$ cells. The analysis of cellular responses has been determined by various methods including $\mathrm{T}$ cell proliferation (lymphoproliferative assays (LPA)), chromium release assays, Enzyme-linked immunosorbent spot assays (ELISpot), interferon gamma release assays, and intracellular cytokine staining (ICC) assays.

To date, LFA and chromium release assays have been limited to evaluating immune response in rodents and primarily in mice. LFAs are unique in that they allow the assessment of both $\mathrm{CD}^{+}$and $\mathrm{CD} 8^{+}$or when fractionated $\mathrm{CD}^{+}$or $\mathrm{CD}^{+} \mathrm{T}$ cell proliferation. In the presence of radioactive (i.e., thymidine) or nonradioactive molecules, which are incorporated into DNA during proliferation, a stimulation index can be determined for a protein or peptide antigen. Similarly, the chromium release assay is a means to measure specific lysis of target cells expressing antigen by $\mathrm{CD}^{+} \mathrm{T}$ cells; however the assay has been primarily limited to studies with clearly defined MHC systems and primarily for analyzing $\mathrm{T}$ cell responses of vaccinated in-bred mice.

The two primary assays utilized with macaques have been ELISpot- and ICC-based assays. Both assays provide semiquantitative analysis of the total $\mathrm{T}$ lymphocyte responses or analysis of indicators of $\mathrm{T}$ cell activation such as cytokine production in ex vivo from vaccine-induced $\mathrm{T}$ cells or virus specific responses following infection. In EliSPOT or ICS, the percentage of cytokine producing (IFN $\gamma$, IL-2, or TNFa) $\mathrm{CD}^{+}$or $\mathrm{CD}^{+} \mathrm{T}$ cells is measured $[41,48,110-112]$.

The ELISPOT assay is considered by many to be a gold standard for monitoring specific cellular immune responses, especially in humans. The assay can detect single cells secreting molecules primarily cytokines following exposure to a specific antigen [112-114]. Overall the assay is highly sensitive, quantitative, easy to use, and amenable to high throughput [115]. The IFN $\gamma$ ELISPOT has been widely used in other vaccine efforts (i.e., HIV, Tuberculosis) to assess the quantification and characterization of the $\mathrm{CD} 8^{+}$ $\mathrm{T}$ cell responses [113]. Thus it has several unique advantages including the following (1) it provides a reliable and suitable method to directly measure antigen-specific $\mathrm{T}$ cells with limited ex vivo expansion of cells during the assay, (2) it typically requires fewer cells and can utilize cryopreserved cells, (3) it has been correlated to provide similar immune responses assessments in both macaques and humans [116], and (4) equipment requirements are lower and overall less technically difficult to perform than ICC assays. Despite the many positive attributes of the assay, the assay was used in rodent studies but was less predictive than other cellular assays. [96]. Furthermore, the predictive power of this assay in humans has become questionable since the approach did not accurately predict vaccine protection in a recent HIV vaccine trail [117]. Improvements in ELISpot assays and reagents and the potential of multidimensional, dual color cytokine ELISpot assays [118] may increase the value of this approach in the future.

ICC methods have been the primary method to assess cellular responses in macaques. To date, these assays have relied on three- to four-color flow cytometry. In these assays, irradiated virus, recombinant proteins, or overlapping peptides have been used to stimulate rodent or macaque PBMCs ex vivo $[41,86,96,102,119,120]$. As expected, there are numerous "positive" responses after vaccination, likely due to the vast activation of specific and nonantigen-specific (i.e., vector directed responses) lymphocyte responses generated after antigen exposure by the various vaccine platforms which often involve a viral vector or adjuvant. As described by Sullivan et al., we have also observed low $\mathrm{CD}^{+}$and $\mathrm{CD}^{+} \mathrm{T}$ cell responses (near the assay limits of detection) or inconsistently observed responses in the same macaque after vaccination ([120] and unpublished data) and, thus, the reliability of these responses has been questioned as the responses are rarely consistently observed after booster vaccinations, challenge, or in convalescent animals. The traditional ex vivo assessment of cellular immunity after vaccination likely lacks the sensitivity needed to detect the relevant determinants of cell-mediated immunity and are unable to differentiate the functional attributes (memory or effector phenotypes) of the responses observed. Furthermore, sampling blood volume limits severely impair the analysis that can be achieved after vaccination in experimental animal models. The use of out-bred models is more difficult than the described inbred mouse studies due to the various MHCs within the models and further complicated by the lack of reagents to monitor cellular responses. For example, while there are easily obtainable methods to analyze $\mathrm{CD} 8^{+}$ $\mathrm{T}$ cell responses in in-bred mice with MHC class I tetramer molecule technologies, there are limited reagents available for macaques to monitor virus-specific cellular immunity.

Newer, more-sensitive methods for analysis of cellular immunity offer promise for more-detailed assessment of $\mathrm{T}$ cell phenotype and function. Another emerging approach to measure cellular responses is the use of multiparameter flow cytometry. The aforementioned techniques used for 
filoviruses reveal a cellular reactivity to virus protein(s); however the data lack critical information that can discriminate between "good" or nonprotective immunity. Thus, the issue is the relative values of the easily obtained data (magnitude of the response to antigen) and the more difficult assays which ascertain the sensitivity/specificity of the immune response. The later aspect has been difficult to assess in the past and can be costly to obtain. Assays for both magnitude and quality of the response have been best described by Roederer et al. for the development of multicolor flow cytometry methods to assess $\mathrm{T}$ cell frequency and, more importantly, T cell quality in memory and effector cells $[121,122]$. The key aspect is that the clonal expansion of antigen-specific $\mathrm{T}$ cells results in a heterogeneous population of epitope/antigen-specific responses. These cells vary considerabl in functional capacity and some may even lack function as determined by lytic activity. Thus, an analysis of "magnitude" by ELISpot or limited ICS, while being informative, lacks critical functional information. Even within the functional subset of cells, there are a variety of cells with varying functional potential with some working as lytic effector cells and others responsible for organizing immune responses (specific cytokine and chemo-attractant producers), to other clones that facilitate proliferation of the clones and other immune cells needed for the response.

Unfortunately, our understanding of these various functional cell subsets is not clear. Therefore, a "good" vaccine cellular response can only be determined empirically using animal model(s) and then translated to human-use. The assays developed by Roederer et al. have defined a method that allows sampling of heterogeneous populations of antigen-specific cells and their relative functional capacities. Multiparametric flow cytometry methods allow for simultaneous $\mathrm{T}$ analysis of several parameters ( $\sim$ four to five parameters and growing [122]). These parameters are often associated with specific functional capacities. Given profiles can be associated with protective $\mathrm{T}$ cell responses when compared to unprotected individuals or animals. The use of this technology has enabled the assessment of the heterogeneous population of cells and correlates them to viral loads in HIV. For example, in HIV a given lymphocyte profile was established for viral load in long-term non-progressors (LTNP) versus progressors [121]. In those studies, a subset of $\mathrm{T}$ cells with the greatest multicytokine producing capacity is associated with virus suppression. In the assay, B and T cell phenotypes can be assessed with precision on a singlecell level by exploiting markers of lineage, homing profile and memory phenotypes. Such phenotypes can be defined further by their functional profiles such as effectors, memory or having the ability to express multiple cytokines (i.e., TNF$\alpha$, IL-2, and INF- $\gamma$ ).

In initial work by Sullivan et al., they suggest that similar profiles exist for protective responses to filoviruses [85] and the approach may be useful in bridging preclinical macaque studies to human clinical studies. While prechallenge serum antibody titers (IgG against GP by ELISA) have been fairly good at predicting survival in vaccinated macaques for nearly all of the vaccine platforms tested, the use of multiparameter flow cytometry to analyze specific phenotypic and functional markers of cellular immunity appears to enhance the ability to predict protection after vaccination [85]. Therefore, the use of additional immune correlates, such as cellular immune assays may be useful in vaccine licensure especially as the vaccines are assessed in clinical studies with animals and humans as the translation of protection may vary between species. Similar to studies described with rAd5-based vaccines, our own studies with VLP- and VEE replicon-based vaccines suggest that the ability of virus-specific T cells $\left(\mathrm{CD}^{+}\right.$and $\mathrm{CD}^{+}$) to produce two or more cytokines and IgG titers to the viral GP has been associated with a protective immunity (unpublished observation). The use of this type of assay in examining human responses to filovirus vaccines is discussed hereinafter. While the ability to utilize novel methods to assess cellular assays such as multiparameter ( $>10$ colors) flow cytometry and mass spectrometry methods to assess cellular response appears to be important for monitoring prechallenge responses in vaccinated animals, the use of these types of assays in filovirus-challenged animals is technically constrained in many high-containment laboratories. New biosafety level- (BSL-) 4 facility designs, optimization of assays, and miniaturization of equipment should allow the measurement of cellular responses which are currently impractical.

5.4. Human Filovirus Vaccine Studies: An Opportunity to Evaluate the Role of CTLs. Due to the nature of filovirus hemorrhagic fever, efficacy trials in humans are not ethical. Primary objectives of clinical testing efforts for filovirus vaccines will be the safety and immunogenicity of different dosage levels of the candidate filovirus vaccine [85]. FDA approval of a filovirus vaccine for broad (nonemergency) use in humans will require licensure via the FDA "animal rule" guidance having pivotal efficacy studies in animals (presumptively NHP models that most closely mimic human disease) being performed concurrently with clinical trials, thus allowing correlates or surrogate markers of protection identified in animals to be linked with the performance of the vaccine candidates in humans $[85,109]$. To date, there have been two publications from the Vaccine Research Center of NIAID, NIH regarding clinical trials testing safety and immunogenicity of DNA and adenovirus-based filovirus vaccines $[103,104]$.

In the first clinical trial of a filovirus vaccine, 27 subjects were vaccinated in a dose-escalation study having four tiers of $0,2,4$, or $8 \mathrm{mg}$ of DNA given three times at $>21$ day intervals [103]. The DNA vaccine consisted of three plasmid components encoding the ZEBOV or SEBOV GP or the ZEBOV NP. The vaccine was generally welltolerated with only one subject in the $2 \mathrm{mg}$ dose group and two subjects in the $8 \mathrm{mg}$ dose group not receiving all three injections. In all vaccines receiving the Ebola DNA vaccine, virus-specific antibody responses were observed; however, not all subjects generated antibodies to all three components as measured by western blotting and ELISA [103]. None of the subjects generated detectable virus-neutralizing antibodies [103]. T cell responses were tested using intracellular cytokine staining (ICS) and ELISPOT assays with stronger responses to SEBOV GP than ZEBOV GP and ZEBOV NP was the least 
immunogenic. $\mathrm{CD}^{+} \mathrm{T}$ cell responses were observed at some point in the trial duration in all vaccinees; however, $\mathrm{CD} 8^{+}$ $\mathrm{T}$ cell responses were observed less frequently (100\% versus $30 \%)$ and to a lower extent [103]. While the results of this trial were encouraging in demonstrating safety and immunogenicity in humans, the DNA vaccine has not been demonstrated to provide complete protection against $\mathrm{EBOV}$ infection in NHP.

In the second clinical trial, a replication-defective adenovirus serotype 5 (Ad5) vaccine expressing the ZEBOV and SEBOV GPs was tested in 31 human volunteers with 23 receiving the Ad5 vaccine [104]. Three groups of patients were administered one of two doses of vaccine $\left(2 \times 10^{9}\right.$ or $2 \times 10^{10}$ VP, for example, "low" and "high" dose, resp.) or placebo given once intramuscularly on day 0 and the volunteers were followed for 48 weeks [104]. Mild local site reactions were noted in a majority of patients receiving vaccine (15 of 23 versus 1 of 8 in the placebo group) and mild-to-severe systemic symptoms were observed in $48 \%$ (11 of 23) of vaccinees versus $25 \%$ (two of eight having mild systemic reactions) of those receiving a placebo injection. Four weeks after the vaccination, 58\% and 100\% of low- and high-dose vaccinees, respectively, were positive for antibodies to SEBOV GP while 50\% and 55\% of lowand high-dose vaccines were seropositive for ZEBOV GP by ELISA. Overall, antibody responses were maintained through 48 weeks in the low-dose group in $42 \%$ (SEBOV GP) and $33 \%$ (ZEBOV GP) of vaccinees and in $60 \%$ (SEBOV GP) and 40\% (ZEBOV GP) of vaccinees in the high-dose group. No positive antibody responses were observed in placebo recipients. Preexisting immunity to Ad5 seemed to affect the outcome of vaccination, as Ad5-seronegative subjects had a significantly higher antibody titers, as well as response rate, when compared to the Ad5-seropositive subjects. Interestingly, using an ELISpot assay to assess bulk $\mathrm{T}$ cell responses, slightly higher response rates were observed in low-dose vaccinees when compared to high-dose vaccinees (27\% versus $25 \%$ for SEBOV GP and $45 \%$ versus $25 \%$ for ZEBOV GP, resp.) at 4 weeks postvaccination. In contrast, GP-specific CD4 responses were seen in $42 \%$ and $82 \%$ of vaccinees in the low- and high-dose groups for SEBOV GP and in 33\% and $64 \%$ of vaccinees for ZEBOV GP. Overall, CD8 $\mathrm{T}$ cell responses were significantly lower than the CD4 T cell responses with 8 and $9 \%$ of low- and high-dose vaccinees having detectable CD8 $\mathrm{T}$ cell responses to SEBOV GP and 0 and $27 \%$ of low- and high-dose vaccinees having CD8 T cell responses to ZEBOV GP at 4 weeks post vaccination. The rate of $\mathrm{T}$ cell responses in vaccinees did not seem to be affected by preexisting immunity to Ad5, although the number of volunteers having $\mathrm{T}$ cell responses was low [104].

The reports for the first two clinical trials of filovirus vaccines show the ability to successful induce filovirus-specific humoral and cellular responses $[103,104]$. The assays used to detect $\mathrm{T}$ cell responses in the first two clinical trials for $\mathrm{EBOV}$ vaccines were ICS (flow cytometry-based) and ELISPOT assay $[103,104]$. In both assays, the most immunogenic component was the SEBOV GP. The most prevalent response discovered was that of $\mathrm{CD} 4^{+} \mathrm{T}$ cells, as detected using the ICS assay. The ICS assay appeared to be much more sensitive than the ELISPOT assay, which detected $\mathrm{T}$ cell responses in far fewer individuals $[103,104]$. Given the apparent important role of $\mathrm{T}$ cells in vaccine-mediated protection, the use of a $\mathrm{T}$ cell assay in assessing immune responses to filovirus vaccines will be important in human clinical trials and also pivotal animal efficacy trials. The challenge will be bridging these highly technical and complicated assays into use for large Phase 3 immunogenicity studies, where large numbers of samples collected at multiple studies sites will likely be required.

\section{Conclusions and Future Directions}

Because of their lethality and other key properties that characterize the filoviruses as a bioweapon threat, a focused effort to develop medical countermeasures has been directed against EBOV and MARV infections [123]. With the development of mouse models of disease $[80,124]$, reagents for examination and depletion of specific immune cell populations in nonhuman primates, and the success of vaccines and therapeutics, the ability to tease the protective immune response has been begun [85]. While humoral responses to the virus are clearly important, there is mounting evidence that filovirus-specific $\mathrm{CD}^{+}$CTLs are necessary for viral control and clearance $[86,96]$. The roles of $\mathrm{T}$ cells in protection are being assessed as multiple vaccine candidates are tested in NHP efficacy trials and, ultimately, in clinical trial volunteers. Although we have learned a great deal about the consequences of either an inadequate or robust CTL response after vaccination or infection in various animal models, few data are available from human survivors of EBOV or MARV. T cell assays must be developed with relevance to future human clinical studies in mind. Human trials will require robust assays for monitoring immune responses for eventual licensure of the human-use filovirus vaccine(s). For this purpose, further investigation of immune responses in both natural filovirus infection and active immunization in humans must be continued and expanded.

\section{Acknowledgments}

The authors thank Sabrina Stronsky for reference assistance and support. Dr. Olinger is supported by the U.S. Army and the Defense Threat Reduction Agency funding to develop assays for assessing protective responses following virus infection. Opinions, interpretations, conclusions, and recommendations are those of the authors and are not necessarily endorsed by the U.S. Army.

\section{References}

[1] J. S. Towner, T. K. Sealy, M. L. Khristova et al., "Newly discovered Ebola virus associated with hemorrhagic fever outbreak in Uganda," PLoS Pathogens, vol. 4, no. 11, Article ID e1000212, 2008.

[2] A. Sanchez, M. P. Kiley, B. P. Holloway, and D. D. Auperin, "Sequence analysis of the Ebola virus genome: organization, genetic elements, and comparison with the genome of Marburg virus," Virus Research, vol. 29, no. 3, pp. 215-240, 1993. 
[3] C. F. Basler, X. Wang, E. Mühlberger et al., "The Ebola virus VP35 protein functions as a type I IFN antagonist," Proceedings of the National Academy of Sciences of the United States of America, vol. 97, no. 22, pp. 12289-12294, 2000.

[4] E. Mühlberger, M. Weik, V. E. Volchkov, H. D. Klenk, and S. Becker, "Comparison of the transcription and replication strategies of Marburg virus and ebola virus by using artificial replication systems," Journal of Virology, vol. 73, no. 3, pp. 2333-2342, 1999.

[5] J. Burke, R. Declerq, and G. Ghysebrechts, "Ebola haemorrhagic fever in Zaire, 1976. Report of an international commission," Bulletin of the World Health Organization, vol. 56, no. 2, pp. 271-293, 1978.

[6] I. M. Deng, O. Duku, and A. L. Gillo, "Ebola haemorrhagic fever in Sudan, 1976. Report of a WHO/International Study Team," Bulletin of the World Health Organization, vol. 56, no. 2, pp. 247-270, 1978.

[7] B. M. Connolly, K. E. Steele, K. J. Davis et al., "Pathogenesis of experimental Ebola virus infection in guinea pigs," Journal of Infectious Diseases, vol. 179, supplement 1, pp. S203-S217, 1999.

[8] E. I. Ryabchikova, L. V. Kolesnikova, and S. V. Netesov, "Animal pathology of filoviral infections," Current Topics in Microbiology and Immunology, vol. 235, pp. 145-173, 1999.

[9] U. Ströher, E. West, H. Bugany, H. D. Klenk, H. J. Schnittler, and H. Feldmann, "Infection and activation of monocytes by Marburg and Ebola viruses," Journal of Virology, vol. 75, no. 22, pp. 11025-11033, 2001.

[10] E. M. Leroy, B. Kumulungui, X. Pourrut et al., "Fruit bats as reservoirs of Ebola virus," Nature, vol. 438, no. 7068, pp. 575576, 2005.

[11] J. S. Towner, X. Pourrut, C. G. Albariño et al., "Marburg virus infection detected in a common African bat," PLoS ONE, vol. 2, no. 8, article e764, 2007.

[12] E. F. Belanov, V. P. Muntianov, V. D. Kriuk et al., "Survival of Marburg virus infectivity on contaminated surfaces and in aerosols," Voprosy Virusologii, vol. 41, no. 1, pp. 32-34, 1996.

[13] V. G. Frolov and I. M. Gusev, "Stability of Marburg virus to lyophilization process and subsequent storage at different temperatures," Voprosy Virusologii, vol. 41, no. 6, pp. 275277, 1996.

[14] E. Johnson, N. Jaax, J. White, and P. Jahrling, "Lethal experimental infections of rhesus monkeys by aerosolized Ebola virus," International Journal of Experimental Pathology, vol. 76, no. 4, pp. 227-236, 1995.

[15] E. Ryabchikova, L. Strelets, L. Kolesnikova, O. Pyankov, and A. Sergeev, "Respiratory Marburg virus infection in guinea pigs," Archives of Virology, vol. 141, no. 11, pp. 2177-2190, 1996.

[16] N. K. Jaax, K. J. Davis, T. J. Geisbert et al., "Lethal experimental infection of rhesus monkeys with Ebola-Zaire (Mayinga) virus by the oral and conjunctival route of exposure," Archives of Pathology and Laboratory Medicine, vol. 120, no. 2, pp. 140-155, 1996.

[17] M. Mohamadzadeh, L. Chen, and A. L. Schmaljohn, "How Ebola and Marburg viruses battle the immune system," Nature Reviews Immunology, vol. 7, no. 7, pp. 556-567, 2007.

[18] D. S. Reed and M. Mohamadzadeh, "Status and challenges of filovirus vaccines," Vaccine, vol. 25, no. 11, pp. 1923-1934, 2007.

[19] M. Hevey, D. Negley, L. VanderZanden et al., "Marburg virus vaccines: comparing classical and new approaches," Vaccine, vol. 20, no. 3-4, pp. 586-593, 2001.
[20] G. M. Ignat'ev, M. A. Strel'tsova, A. P. Agafonov, N. A. Zhukova, E. A. Kashentseva, and M. S. Vorob'eva, "The immunity indices of animals immunized with the inactivated Marburg virus after infection with homologous virus," Voprosy Virusologii, vol. 39, no. 1, pp. 13-17, 1994.

[21] G. M. Ignatev, A. P. Agafonov, M. A. Strel'tsova et al., "A comparative study of the immunological indices in guinea pigs administered an inactivated Marburg virus," Voprosy Virusologii, vol. 36, pp. 421-423, 1991.

[22] G. M. Ignatyev, A. P. Agafonov, M. A. Streltsova, and E. A. Kashentseva, "Inactivated marburg virus elicits a nonprotective immune response in Rhesus monkeys," Journal of Biotechnology, vol. 44, no. 1-3, pp. 111-118, 1996.

[23] T. W. Geisbert, P. Pushko, K. Anderson, J. Smith, K. J. Davis, and P. B. Jahrling, "Evaluation in nonhuman primates of vaccines against Ebola virus," Emerging Infectious Diseases, vol. 8, no. 5, pp. 503-507, 2002.

[24] H. W. Lupton, R. D. Lambert, and D. L. Bumgardner, "Inactivated vaccine for Ebola virus efficacious in guinea pig model," The Lancet, vol. 2, no. 8207, pp. 1294-1295, 1980.

[25] M. Rao, M. Bray, C. R. Alving, P. Jahrling, and G. R. Matyas, "Induction of immune responses in mice and monkeys to Ebola virus after immunization with liposome-encapsulated irradiated ebola virus: protection in mice requires CD4+ T cells," Journal of Virology, vol. 76, no. 18, pp. 9176-9185, 2002.

[26] T. W. Geisbert and P. B. Jahrling, "Towards a vaccine against Ebola virus," Expert Review of Vaccines, vol. 2, no. 6, pp. 777789, 2003.

[27] V. V. Mikhailov, I. V. Borisevich, N. K. Chernikova, N. V. Potryvaeva, and V. P. Krasnianskii, "The evaluation in hamadryas baboons of the possibility for the specific prevention of Ebola fever," Voprosy Virusologii, vol. 39, no. 2, pp. 82-84, 1994.

[28] M. Hevey, D. Negley, J. Geisbert, P. Jahrling, and A. Schmaljohn, "Antigenicity and vaccine potential of Marburg virus glycoprotein expressed by baculovirus recombinants," Virology, vol. 239, no. 1, pp. 206-216, 1997.

[29] J. Riemenschneider, A. Garrison, J. Geisbert et al., "Comparison of individual and combination DNA vaccines for B. anthracis, Ebola virus, Marburg virus and Venezuelan equine encephalitis virus," Vaccine, vol. 21, no. 25-26, pp. 40714080, 2003.

[30] T. W. Geisbert, M. Bailey, J. B. Geisbert et al., "Vector choice determines immunogenicity and potency of genetic vaccines against Angola Marburg virus in nonhuman primates," Journal of Virology, vol. 84, no. 19, pp. 10386-10394, 2010.

[31] J. L. Mellquist-Riemenschneider, A. R. Garrison, J. B. Geisbert et al., "Comparison of the protective efficacy of DNA and baculovirus-derived protein vaccines for Ebola virus in guinea pigs," Virus Research, vol. 92, no. 2, pp. 187-193, 2003.

[32] K. Konduru, S. B. Bradfute, J. Jacques et al., "Ebola virus glycoprotein $\mathrm{Fc}$ fusion protein confers protection against lethal challenge in vaccinated mice," Vaccine, vol. 29, no. 16, pp. 2968-2977, 2011.

[33] M. K. Hart, "Vaccine research efforts for filoviruses," International Journal for Parasitology, vol. 33, no. 5-6, pp. 583-595, 2003.

[34] M. Garbutt, R. Liebscher, V. Wahl-Jensen et al., "Properties of replication-competent vesicular stomatitis virus vectors expressing glycoproteins of filoviruses and arenaviruses," Journal of Virology, vol. 78, no. 10, pp. 5458-5465, 2004.

[35] P. Pushko, J. Geisbert, M. Parker, P. Jahrling, and J. Smith, "Individual and bivalent vaccines based on alphavirus 
replicons protect guinea pigs against infection with Lassa and Ebola viruses," Journal of Virology, vol. 75, no. 23, pp. 1167711685, 2001.

[36] P. Pushko, M. Bray, G. V. Ludwig et al., "Recombinant RNA replicons derived from attenuated Venezuelan equine encephalitis virus protect guinea pigs and mice from Ebola hemorrhagic fever virus," Vaccine, vol. 19, no. 1, pp. 142-153, 2000.

[37] J. A. Wilson and M. K. Hart, "Protection from Ebola virus mediated by cytotoxic $\mathrm{T}$ lymphocytes specific for the viral nucleoprotein," Journal of Virology, vol. 75, no. 6, pp. 2660 2664, 2001.

[38] M. Hevey, D. Negley, P. Pushko, J. Smith, and A. Schmaljohn, "Marburg virus vaccines based upon alphavirus replicons protect guinea pigs and nonhuman primates," Virology, vol. 251, no. 1, pp. 28-37, 1998.

[39] N. J. Sullivan, A. Sanchez, P. E. Rollin, Z. Y. Yang, and G. J. Nabel, "Development of a preventive vaccine for Ebola virus infection in primates," Nature, vol. 408, no. 6812, pp. 605 $609,2000$.

[40] G. J. Nabel, "Vaccine for AIDS and Ebola virus infection," Virus Research, vol. 92, no. 2, pp. 213-217, 2003.

[41] N. J. Sullivan, T. W. Geisbert, J. B. Gelsbert et al., "Accelerated vaccination for Ebola virus haemorrhagic fever in nonhuman primates," Nature, vol. 424, no. 6949, pp. 681-684, 2003.

[42] A. Bukreyev, P. E. Rollin, M. K. Tate et al., "Successful topical respiratory tract immunization of primates against Ebola virus," Journal of Virology, vol. 81, no. 12, pp. 6379-6388, 2007.

[43] A. Bukreyev, L. Yang, S. R. Zaki et al., "A single intranasal inoculation with a paramyxoviras-vectored vaccine protects guinea pigs against a lethal-dose ebola virus challenge," Journal of Virology, vol. 80, no. 5, pp. 2267-2279, 2006.

[44] D. Falzarano, T. W. Geisbert, and H. Feldmann, "Progress in filovirus vaccine development: evaluating the potential for clinical use," Expert Review of Vaccines, vol. 10, no. 1, pp. 6377, 2011.

[45] D. G. Bausch, A. G. Sprecher, B. Jeffs, and P. Boumandouki, "Treatment of Marburg and Ebola hemorrhagic fevers: a strategy for testing new drugs and vaccines under outbreak conditions," Antiviral Research, vol. 78, no. 1, pp. 150-161, 2008.

[46] T. W. Geisbert, L. E. Hensley, P. B. Jahrling et al., "Treatment of Ebola virus infection with a recombinant inhibitor of factor VIIa/tissue factor: a study in rhesus monkeys," The Lancet, vol. 362, no. 9400, pp. 1953-1958, 2003.

[47] L. E. Hensley, E. L. Stevens, S. B. Yan et al., "Recombinant human activated protein $\mathrm{C}$ for the postexposure treatment of ebola hemorrhagic fever," Journal of Infectious Diseases, vol. 196, no. 2, pp. S390-S399, 2007.

[48] K. M. Daddario-DiCaprio, T. W. Geisbert, U. Ströher et al., "Postexposure protection against Marburg haemorrhagic fever with recombinant vesicular stomatitis virus vectors in non-human primates: an efficacy assessment," The Lancet, vol. 367, no. 9520, pp. 1399-1404, 2006.

[49] S. M. Jones, U. Ströher, L. Fernando et al., "Assessment of a vesicular stomatitis virus-based vaccine by use of the mouse model of Ebola virus hemorrhagic fever," Journal of Infectious Diseases, vol. 196, supplement 2, pp. S404-S412, 2007.

[50] H. Feldmann, S. M. Jones, K. M. Daddario-DiCaprio et al., "Effective post-exposure treatment of Ebola infection," PLoS Pathogens, vol. 3, no. 1, p. e2, 2007.
[51] K. L. Warfield, D. L. Swenson, G. G. Olinger et al., "Gene-specific countermeasures against Ebola virus based on antisense phosphorodiamidate morpholino oligomers," PLoS Pathogens, vol. 2, no. 1, p. e1, 2006.

[52] T. K. Warren, K. L. Warfield, J. Wells et al., "Advanced antisense therapies for postexposure protection against lethal filovirus infections," Nature Medicine, vol. 16, no. 9, pp. 991994, 2010.

[53] T. W. Geisbert, L. E. Hensley, E. Kagan et al., "Postexposure protection of guinea pigs against a lethal ebola virus challenge is conferred by RNA interference," Journal of Infectious Diseases, vol. 193, no. 12, pp. 1650-1657, 2006.

[54] T. W. Geisbert, A. C. Lee, M. Robbins et al., "Postexposure protection of non-human primates against a lethal Ebola virus challenge with RNA interference: a proof-of-concept study," The Lancet, vol. 375, no. 9729, pp. 1896-1905, 2010.

[55] S. Baize, E. M. Leroy, M. C. Georges-Courbot et al., "Defective humoral responses and extensive intravascular apoptosis are associated with fatal outcome in Ebola virusinfected patients," Nature Medicine, vol. 5, no. 4, pp. 423-426, 1999.

[56] Y. J. Liu, "Dendritic cell subsets and lineages, and their functions in innate and adaptive immunity," Cell, vol. 106, no. 3, pp. 259-262, 2001.

[57] R. M. Steinman, "Dendritic cells and the control of immunity: enhancing the efficiency of antigen presentation," Mount Sinai Journal of Medicine, vol. 68, no. 3, pp. 160-166, 2001.

[58] E. M. Leroy, S. Baize, P. Debre, J. Lansoud-Soukate, and E. Mavoungou, "Early immune responses accompanying human asymptomatic Ebola infections," Clinical and Experimental Immunology, vol. 124, no. 3, pp. 453-460, 2001.

[59] E. M. Leroy, S. Baize, V. E. Volchkov et al., "Human asymptomatic Ebola infection and strong inflammatory response," The Lancet, vol. 355, no. 9222, pp. 2210-2215, 2000.

[60] S. Baize, E. M. Leroy, A. J. Georges et al., "Inflammatory responses in Ebola virus-infected patients," Clinical and Experimental Immunology, vol. 128, no. 1, pp. 163-168, 2002.

[61] K. L. Hutchinson and P. E. Rollin, "Cytokine and chemokine expression in humans infected with Sudan Ebola virus," Journal of Infectious Diseases, vol. 196, no. 2, pp. S357-S363, 2007.

[62] F. Villinger, P. E. Rollin, S. S. Brar et al., "Markedly elevated levels of interferon (IFN)- $\gamma$, IFN- $\alpha$, interleukin (IL)-2, IL-10, and tumor necrosis factor- $\alpha$ associated with fatal Ebola virus infection," Journal of Infectious Diseases, vol. 179, no. 1, pp. S188-S191, 1999.

[63] N. Wauquier, P. Becquart, C. Padilla, S. Baize, and E. M. Leroy, "Human fatal zaire ebola virus infection is associated with an aberrant innate immunity and with massive lymphocyte apoptosis," PLoS Neglected Tropical Diseases, vol. 4, no. 10, article e837, 2010.

[64] M. Gupta, S. Mahanty, R. Ahmed, and P. E. Rollin, "Monocyte-derived human macrophages and peripheral blood mononuclear cells infected with Ebola virus secrete MIP- $1 \alpha$ and TNF- $\alpha$ and inhibit poly-IC-induced IFN- $\alpha$ in vitro," Virology, vol. 284, no. 1, pp. 20-25, 2001.

[65] C. F. Basler and G. K. Amarasinghe, "Evasion of interferon responses by ebola and marburg viruses," Journal of Interferon and Cytokine Research, vol. 29, no. 9, pp. 511-520, 2009.

[66] C. M. Bosio, M. J. Aman, C. Grogan et al., "Ebola and Marburg viruses replicate in monocyte-derived dendritic 
cells without inducing the production of cytokines and full maturation," Journal of Infectious Diseases, vol. 188, no. 11, pp. 1630-1638, 2003.

[67] S. Mahanty, K. Hutchinson, S. Agarwal, M. Mcrae, P. E. Rollin, and B. Pulendran, "Cutting edge: impairment of dendritic cells and adaptive immunity by Ebola and Lassa viruses," Journal of Immunology, vol. 170, no. 6, pp. 27972801, 2003.

[68] T. W. Geisbert, L. E. Hensley, T. Larsen et al., "Pathogenesis of ebola hemorrhagic fever in cynomolgus macaques: evidence that dendritic cells are early and sustained targets of infection," American Journal of Pathology, vol. 163, no. 6, pp. 2347-2370, 2003.

[69] L. E. Hensley, H. A. Young, P. B. Jahrling, and T. W. Geisbert, "Proinflammatory response during Ebola virus infection of primate models: possible involvement of the tumor necrosis factor receptor superfamily," Immunology Letters, vol. 80, no. 3, pp. 169-179, 2002.

[70] T. R. Gibb, D. A. Norwood Jr., N. Woollen, and E. A. Henchal, "Viral replication and host gene expression in alveolar macrophages infected with Ebola virus (Zaire strain)," Clinical and Diagnostic Laboratory Immunology, vol. 9, no. 1, pp. 19-27, 2002.

[71] D. S. Reed, L. E. Hensley, J. B. Geisbert, P. B. Jahrling, and T. W. Geisbert, "Depletion of peripheral blood T lymphocytes and NK cells during the course of Ebola hemorrhagic fever in cynomolgus macaques," Viral Immunology, vol. 17, no. 3, pp. 390-400, 2004.

[72] K. L. Warfield, J. G. Perkins, D. L. Swenson et al., "Role of natural killer cells innate protection against lethal Ebola virus infection," Journal of Experimental Medicine, vol. 200, no. 2, pp. 169-179, 2004.

[73] T. W. Geisbert, K. M. Daddario-DiCaprio, K. J. N. Williams et al., "Recombinant vesicular stomatitis virus vector mediates postexposure protection against Sudan Ebola hemorrhagic fever in nonhuman primates," Journal of Virology, vol. 82, no. 11, pp. 5664-5668, 2008.

[74] S. P. Fisher-Hoch, G. S. Platt, and G. H. Neild, "Pathophysiology of shock and hemorrhage in a fulminating viral infection (Ebola)," Journal of Infectious Diseases, vol. 152, no. 5, pp. 887-894, 1985.

[75] S. Kim, K. Iizuka, H. L. Aguila, I. L. Weissman, and W. M. Yokoyama, "In vivo natural killer cell activities revealed by natural killer cell-deficient mice," Proceedings of the National Academy of Sciences of the United States of America, vol. 97, no. 6, pp. 2731-2736, 2000.

[76] N. Wauquier, C. Padilla, P. Becquart, E. Leroy, and V. Vieillard, "Association of KIR2DS1 and KIR2DS3 with fatal outcome in Ebola virus infection," Immunogenetics, vol. 62, no. 11-12, pp. 767-771, 2010.

[77] M. Gupta, C. Spiropoulou, and P. E. Rollin, "Ebola virus infection of human PBMCs causes massive death of macrophages, CD4 and CD8 T cell sub-populations in vitro," Virology, vol. 364, no. 1, pp. 45-54, 2007.

[78] L. E. Hensley, H. A. Young, P. B. Jahrling, and T. W. Geisbert, "Proinflammatory response during Ebola virus infection of primate models: possible involvement of the tumor necrosis factor receptor superfamily," Immunology Letters, vol. 80, no. 3, pp. 169-179, 2002.

[79] T. G. Ksiazek, P. E. Rollin, A. J. Williams et al., "Clinical virology of Ebola hemorrhagic fever (EHF): Virus, virus antigen, and IgG and IgM antibody findings among EHF patients in Kikwit, Democratic Republic of the Congo, 1995,"
Journal of Infectious Diseases, vol. 179, no. 1, pp. S177-S187, 1999.

[80] M. Bray, K. Davis, T. Geisbert, C. Schmaljohn, and J. Huggins, "A mouse model for evaluation of prophylaxis and therapy of ebola hemorrhagic fever," Journal of Infectious Diseases, vol. 178, no. 3, pp. 651-661, 1998.

[81] S. B. Bradfute, D. R. Braun, J. D. Shamblin et al., "Lymphocyte death in a mouse model of ebola virus infection," Journal of Infectious Diseases, vol. 196, no. 2, pp. S296-S304, 2007.

[82] S. B. Bradfute, K. L. Warfield, and S. Bavari, "Functional CD8+ T cell responses in lethal ebola virus infection," Journal of Immunology, vol. 180, no. 6, pp. 4058-4066, 2008.

[83] S. B. Bradfute, P. E. Swanson, M. A. Smith et al., "Mechanisms and consequences of ebolavirus-induced lymphocyte apoptosis," Journal of Immunology, vol. 184, no. 1, pp. 327335, 2010.

[84] M. Gupta, S. Mahanty, P. Greer et al., "Persistent infection with Ebola virus under conditions of partial immunity," Journal of Virology, vol. 78, no. 2, pp. 958-967, 2004.

[85] N. J. Sullivan, J. E. Martin, B. S. Graham, and G. J. Nabel, "Correlates of protective immunity for Ebola vaccines: implications for regulatory approval by the animal rule," Nature Reviews Microbiology, vol. 7, no. 5, pp. 393-400, 2009.

[86] K. L. Warfield, G. Olinger, E. M. Deal et al., "Induction of humoral and CD8+ T cell responses are required for protection against lethal ebola virus infection," Journal of Immunology, vol. 175, no. 2, pp. 1184-1191, 2005.

[87] J. A. Wilson, M. Hevey, R. Bakken et al., "Epitopes involved in antibody-mediated protection from Ebola virus," Science, vol. 287, no. 5458, pp. 1664-1666, 2000.

[88] M. Hevey, D. Negley, and A. Schmaljohn, "Characterization of monoclonal antibodies to Marburg virus (strain Musoke) glycoprotein and identification of two protective epitopes," Virology, vol. 314, no. 1, pp. 350-357, 2003.

[89] P. W. H. I. Parren, T. W. Geisbert, T. Maruyama, P. B. Jahrling, and D. R. Burton, "Pre-and postexposure prophylaxis of ebola virus infection in an animal model by passive transfer of a neutralizing human antibody," Journal of Virology, vol. 76, no. 12, pp. 6408-6412, 2002.

[90] A. Takada, H. Ebihara, S. Jones, H. Feldmann, and Y. Kawaoka, "Protective efficacy of neutralizing antibodies against Ebola virus infection," Vaccine, vol. 25, no. 6, pp. 993999, 2007.

[91] N. J. Sullivan, L. Hensley, C. Asiedu et al., "CD8+ cellular immunity mediates rAd5 vaccine protection against Ebola virus infection of nonhuman primates," Nature Medicine, vol. 17, no. 9, pp. 1128-1131, 2011.

[92] W. B. Oswald, T. W. Geisbert, K. J. Davis et al., "Neutralizing antibody fails to impact the course of Ebola virus infection in monkeys," PLoS Pathogens, vol. 3, no. 1, p. e9, 2007.

[93] P. B. Jahrling, J. B. Geisbert, J. R. Swearengen, T. Larsen, and T. W. Geisbert, "Ebola hemorrhagic fever: evaluation of passive immunotherapy in nonhuman primates," Journal of Infectious Diseases, vol. 196, supplement 2, pp. S400-S403, 2007.

[94] J. A. Wilson, M. Bray, R. Bakken, and M. K. Hart, "Vaccine potential of Ebola virus VP24, VP30, VP35, and VP40 proteins," Virology, vol. 286, no. 2, pp. 384-390, 2001.

[95] D. L. Swenson, K. L. Warfield, D. L. Negley, A. Schmaljohn, M. J. Aman, and S. Bavari, "Virus-like particles exhibit potential as a pan-filovirus vaccine for both Ebola and Marburg viral infections," Vaccine, vol. 23, no. 23, pp. 30333042, 2005. 
[96] G. G. Olinger, M. A. Bailey, J. M. Dye et al., "Protective cytotoxic T-cell responses induced by Venezuelan equine encephalitis virus replicons expressing Ebola virus proteins," Journal of Virology, vol. 79, no. 22, pp. 14189-14196, 2005.

[97] J. H. Kuhn, Filoviruses: A Compendium of 40 Years of Epidemiological, Clinical, and Laboratory Studies, Springer, New York, NY, USA, 2008.

[98] W. Dowling, E. Thompson, C. Badger et al., "Influences of glycosylation on antigenicity, immunogenicity, and protective efficacy of Ebola virus GP DNA vaccines," Journal of Virology, vol. 81, no. 4, pp. 1821-1837, 2007.

[99] M. Rao, G. R. Matyas, F. Grieder, K. Anderson, P. B. Jahrling, and C. R. Alving, "Cytotoxic T lymphocytes to Ebola Zaire virus are induced in mice by immunization with liposomes containing lipid A," Vaccine, vol. 17, no. 23-24, pp. 29912998, 1999.

[100] G. Simmons, A. Lee, A. J. Rennekamp, X. Fan, P. Bates, and H. Shen, "Identification of murine T-cell epitopes in Ebola virus nucleoprotein," Virology, vol. 318, no. 1, pp. 224-230, 2004.

[101] K. Sundar, A. Boesen, and R. Coico, "Computational prediction and identification of HLA-A2.1-specific Ebola virus CTL epitopes," Virology, vol. 360, no. 2, pp. 257-263, 2007.

[102] W. V. Kalina, K. L. Warfield, G. G. Olinger, and S. Bavari, "Discovery of common marburgvirus protective epitopes in a BALB/c mouse model," Virology Journal, vol. 6, article 132, 2009.

[103] J. E. Martin, N. J. Sullivan, M. E. Enama et al., “A DNA vaccine for Ebola virus is safe and immunogenic in a phase I clinical trial," Clinical and Vaccine Immunology, vol. 13, no. 11, pp. 1267-1277, 2006.

[104] J. E. Ledgerwood, P. Costner, N. Desai et al., "A replication defective recombinant Ad5 vaccine expressing Ebola virus GP is safe and immunogenic in healthy adults," Vaccine, vol. 29, no. 2, pp. 304-313, 2010.

[105] T. Vogel, S. Norley, B. Beer, and R. Kurth, "Rapid screening for Mamu-A1-positive rhesus macaques using a SIVmac gag peptide-specific cytotoxic T-lymphocyte assay," Immunology, vol. 84, no. 3, pp. 482-487, 1995.

[106] D. G. Smith, S. Kanthaswamy, J. Viray, and L. Cody, "Additional highly polymorphic microsatellite (STR) loci for estimating kinship in rhesus macaques (Macaca mulatta)," American Journal of Primatology, vol. 50, no. 1, pp. 1-7, 2000.

[107] M. C. T. Penedo, R. E. Bontrop, C. M. C. Heijmans et al., "Microsatellite typing of the rhesus macaque MHC region," Immunogenetics, vol. 57, no. 3-4, pp. 198-209, 2005.

[108] J. R. Napier and P. H. Napier, A Handbook of Living Primates: Morphology, Ecology and Behavior of Nonhuman Primates, Academic Press, New York, NY, USA, 1967.

[109] "Guidance for industry, animal models—essential elements to address efficacy under the animal rule," http://www.fda .gov/downloads/Drugs/GuidanceComplianceRegulatoryInformation/Guidances/ucm078923.pdf.

[110] E. A. Fritz, J. B. Geisbert, T. W. Geisbert, L. E. Hensley, and D. S. Reed, "Cellular immune response to marburg virus infection in cynomolgus macaques," Viral Immunology, vol. 21, no. 3, pp. 355-363, 2008.

[111] S. M. Jones, H. Feldmann, U. Ströher et al., "Live attenuated recombinant vaccine protects nonhuman primates against Ebola and Marburg viruses," Nature Medicine, vol. 11, no. 7, pp. 786-790, 2005.

[112] C. C. Czerkinsky, L. A. Nilsson, and H. Nygren, "A solidphase enzyme-linked immunospot (ELISPOT) assay for enumeration of specific antibody-secreting cells," Journal of Immunological Methods, vol. 65, no. 1-2, pp. 109-121, 1983.

[113] M. Larsson, X. Jin, B. Ramratnam et al., "A recombinant vaccinia virus based ELISPOT assay detects high frequencies of pol-specific CD8 T cells in HIV-1-positive individuals," AIDS, vol. 13, no. 7, pp. 767-777, 1999.

[114] J. R. Currier, E. G. Kuta, E. Turk et al., "A panel of MHC class I restricted viral peptides for use as a quality control for vaccine trial ELISPOT assays," Journal of Immunological Methods, vol. 260, no. 1-2, pp. 157-172, 2002.

[115] M. P. Hernandez-Fuentes, A. N. Warrens, and R. I. Lechler, "Immunologic monitoring," Immunological Reviews, vol. 196, pp. 247-264, 2003.

[116] P. Mooij, S. S. Balla-Jhagjhoorsingh, N. Beenhakker et al., "Comparison of human and rhesus macaque T-cell responses elicited by boosting with NYVAC encoding human immunodeficiency virus type 1 clade C immunogens," Journal of Virology, vol. 83, no. 11, pp. 5881-5889, 2009.

[117] H. Streeck, N. Frahm, and B. D. Walker, "The role of IFN- $\gamma$ Elispot assay in HIV vaccine research," Nature Protocols, vol. 4, no. 4, pp. 461-469, 2009.

[118] Y. Okamoto, T. Abe, T. Niwa, S. Mizuhashi, and M. Nishida, "Development of a dual color enzyme-linked immunospot assay for simultaneous detection of murine T helper type 1and T helper type 2-cells," Immunopharmacology, vol. 39, no. 2, pp. 107-116, 1998.

[119] K. L. Warfield, D. L. Swenson, D. L. Negley, A. L. Schmaljohn, M. J. Aman, and S. Bavari, "Marburg virus-like particles protect guinea pigs from lethal Marburg virus infection," Vaccine, vol. 22, no. 25-26, pp. 3495-3502, 2004.

[120] K. L. Warfield, D. L. Swenson, G. G. Olinger, W. V. Kalina, M. J. Aman, and S. Bavari, "Ebola virus-like particle-based vaccine protects nonhuman primates against lethal Ebola virus challenge," Journal of Infectious Diseases, vol. 196, supplement 2, pp. S430-S437, 2007.

[121] R. A. Seder, P. A. Darrah, and M. Roederer, "T-cell quality in memory and protection: implications for vaccine design," Nature Reviews Immunology, vol. 8, no. 4, pp. 247-258, 2008.

[122] M. Roederer, J. M. Brenchley, M. R. Betts, and S. C. De Rosa, "Flow cytometric analysis of vaccine responses: how many colors are enough?” Clinical Immunology, vol. 110, no. 3, pp. 199-205, 2004.

[123] E. K. Leffel and D. S. Reed, "Marburg and Ebola viruses as aerosol threats," Biosecurity and Bioterrorism, vol. 2, no. 3, pp. 186-191, 2004.

[124] K. L. Warfield, S. B. Bradfute, J. Wells et al., "Development and characterization of a mouse model for Marburg hemorrhagic fever," Journal of Virology, vol. 83, no. 13, pp. 64046415, 2009. 


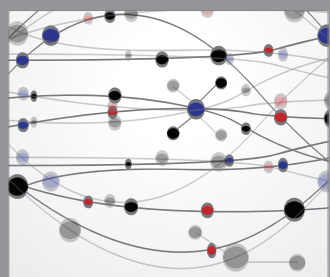

The Scientific World Journal
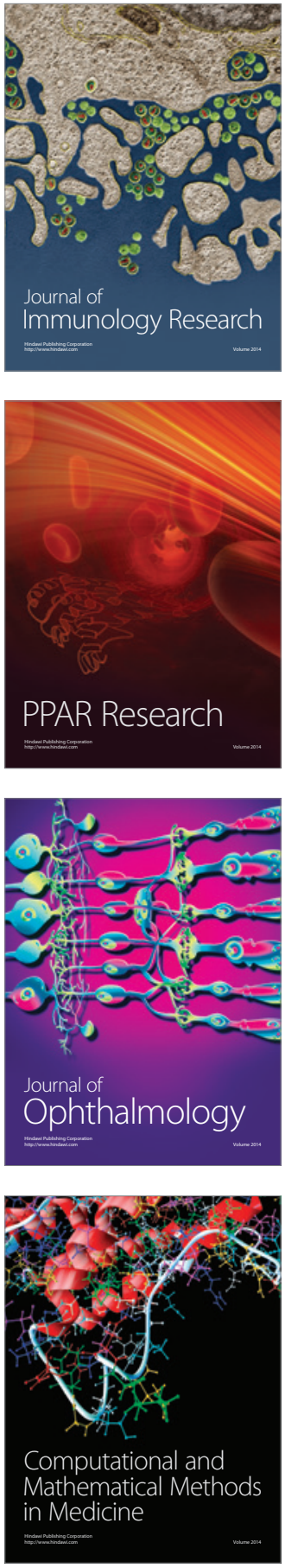

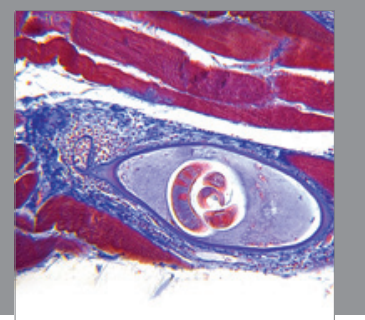

Gastroenterology

Research and Practice
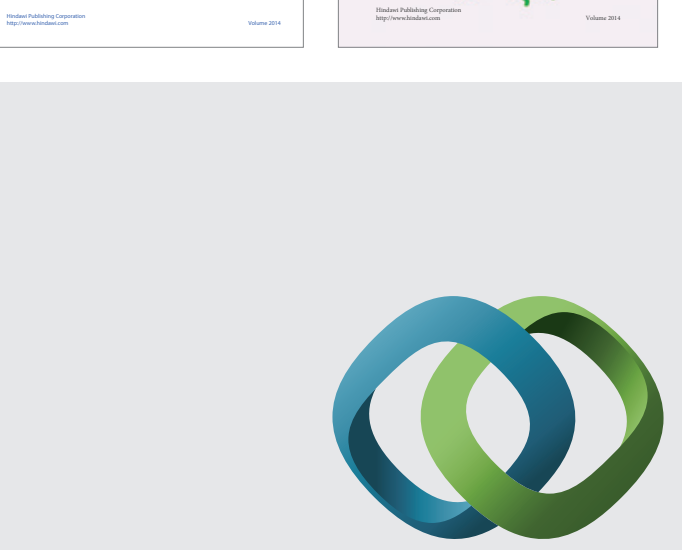

\section{Hindawi}

Submit your manuscripts at

http://www.hindawi.com
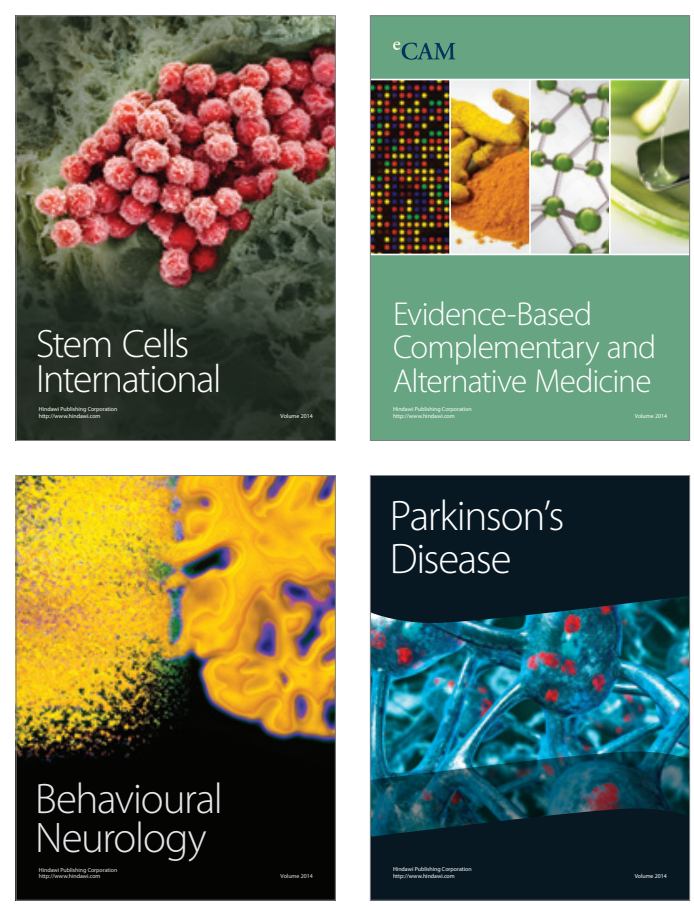

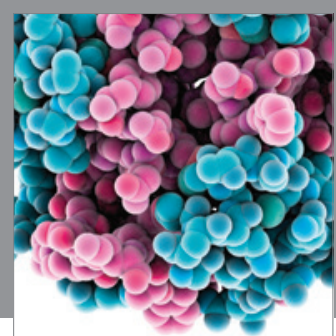

Journal of
Diabetes Research

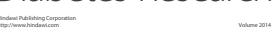

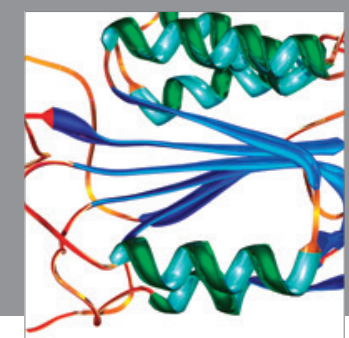

Disease Markers
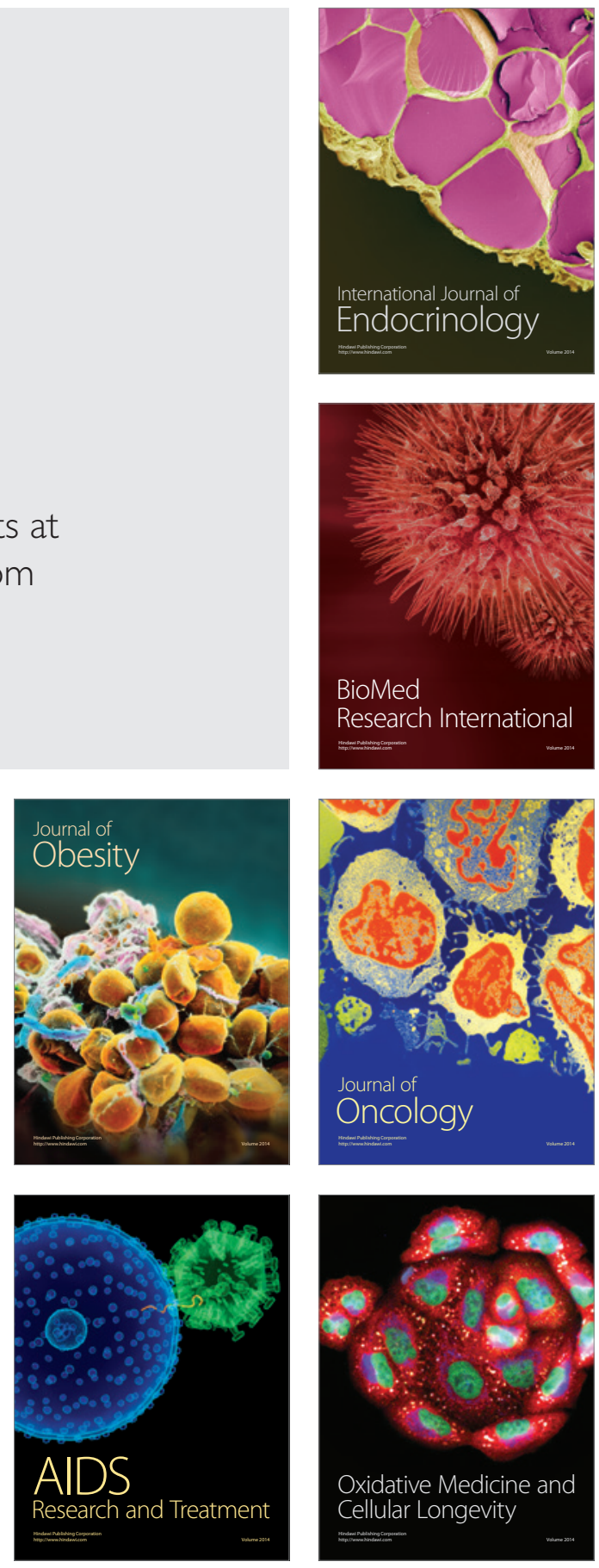